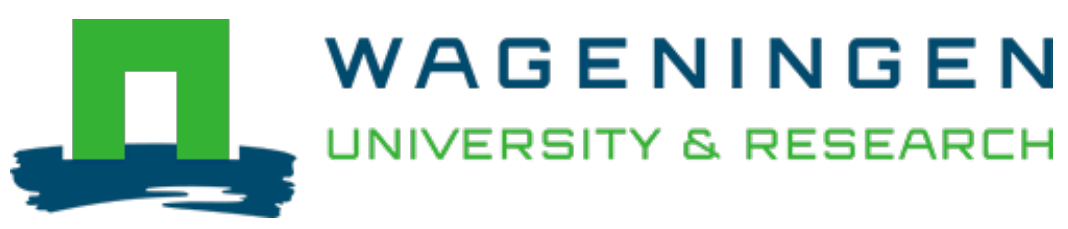

\author{
How the characteristics of innovations impact their adoption : An exploration of \\ climate-smart agricultural innovations in South Africa \\ Journal of Cleaner Production \\ Senyolo, Mmapatla Precious; Long, Thomas B.; Blok, Vincent; Omta, Onno \\ https://doi.org/10.1016/j.jclepro.2017.06.019
}

This article is made publicly available in the institutional repository of Wageningen University and Research, under the terms of article $25 \mathrm{fa}$ of the Dutch Copyright Act, also known as the Amendment Taverne. This has been done with explicit consent by the author.

Article 25 fa states that the author of a short scientific work funded either wholly or partially by Dutch public funds is entitled to make that work publicly available for no consideration following a reasonable period of time after the work was first published, provided that clear reference is made to the source of the first publication of the work.

This publication is distributed under The Association of Universities in the Netherlands (VSNU) 'Article $25 \mathrm{fa}$ implementation' project. In this project research outputs of researchers employed by Dutch Universities that comply with the legal requirements of Article $25 \mathrm{fa}$ of the Dutch Copyright Act are distributed online and free of cost or other barriers in institutional repositories. Research outputs are distributed six months after their first online publication in the original published version and with proper attribution to the source of the original publication.

You are permitted to download and use the publication for personal purposes. All rights remain with the author(s) and / or copyright owner(s) of this work. Any use of the publication or parts of it other than authorised under article $25 \mathrm{fa}$ of the Dutch Copyright act is prohibited. Wageningen University \& Research and the author(s) of this publication shall not be held responsible or liable for any damages resulting from your (re)use of this publication.

For questions regarding the public availability of this article please contact openscience.library@,wur.nl 


\title{
How the characteristics of innovations impact their adoption: An exploration of climate-smart agricultural innovations in South Africa
}

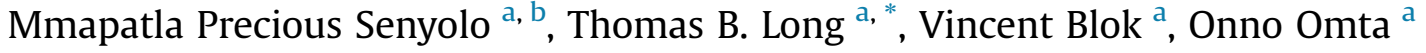 \\ ${ }^{a}$ Wageningen University, Management Studies Group, School of Social Sciences, Hollandseweg 1, 6706 KN, Wageningen, Building 201, The Netherlands \\ ${ }^{\mathrm{b}}$ University of Limpopo, Department of Agricultural Economics, School of Agricultural and Environmental Sciences, Private Bag X1106, Sovenga, 0727, South \\ Africa
}

\section{A R T I C L E I N F O}

\section{Article history:}

Received 24 May 2016

Received in revised form 19 May 2017

Accepted 4 June 2017

Available online $\mathrm{xxx}$

Handling Editor: R.L. Lozano

\section{Keywords:}

Climate-smart agriculture

Technological innovations

Adoption

Farmers

Agriculture

South Africa

\begin{abstract}
A B S T R A C T
Climate change threatens agricultural production and the food security of developing countries in complex ways that demand environmentally friendly innovations. Climate-smart agriculture provides a response to climate change whilst enhancing livelihood of farmers. Climate-smart agricultural technological innovations at farm level have the potential to address climate-related challenges. However, inadequate adoption of these technologies remains a problem. This paper identifies available climate-smart agricultural technological innovations in South Africa and explores their characteristics and context of use using an exploratory research approach. An overview of climate change risks and variability in South Africa and a framework to classify the technological innovations is established based on a literature review. Interviews with expert stakeholders are used to characterise and collect information on available technologies. Results indicate that Conservation Agriculture, Rainwater Harvesting and Seed Varieties that are Drought Tolerant and Early Maturing may be the most suited technologies for climate-smart agriculture in South Africa, particularly for smallholder farmers. However, high initial investment costs, additional labour requirements and management intensity associated with conservation agriculture and rainwater harvesting may pose problems within the South African context. Drought Tolerant and Early Maturing Seed Varieties were noted as less costly and less management intensive, creating better prospects for adoption. This study serves as an initial assessment through the exploration of the available climate-smart agricultural technologies in South Africa. This is essential given that the agricultural sector is faced with the dilemma of responding to climate change related challenges whilst increasing the productivity of farmers.
\end{abstract}

() 2017 Published by Elsevier Ltd.

\section{Introduction}

Climate change threatens the agricultural production and food security of developing countries in complex ways that demand environmentally friendly innovations. Africa's agriculture is vulnerable to climate change (Arslan et al., 2015; Juana et al., 2013), owing to the impact of climate variables such as temperature, humidity and precipitation (IPCC, 2007, 2011), its sensitivity to projected changes and low adaptive capacity (Benhin, 2008; Hellin et al., 2012). Many climate impacts relate to water and therefore consideration of how water is managed, especially in rural and

\footnotetext{
* Corresponding author.

E-mail address: Thomas.long@wur.nl (T.B. Long).
}

agricultural sectors, will be key to climate change adaptation strategies (Hardelin and Lankoski, 2015; UN-Water, 2010). Climate impacts will worsen water scarcity, water quality problems and related socio-economic development issues in South Africa (SA) (New, 2002; Schulze, 2011). Lack of water for agricultural activities remains a major threat to food security, poverty, and sustainable development (Kahinda and Taigbenu, 2011). For instance, droughts which mainly result from the variability in rainfall during the periods of climate stress are a large factor in augmenting food insecurity (Mpandeli et al., 2015). Drought often affects agricultural production in various provinces of South Africa including Limpopo, Free State, parts of Western Cape and Northern Cape. This underlines the importance of understanding the characteristics and availability of different CSA technologies and practices to manage these climate change related threats (Asfaw and Lipper, 2016). The 
effects of water scarcity include loss of livestock, low yields, and a shortage of seed for subsequent cultivation (Maponya and Mpandeli, 2012a). Evidently, shortage of water and droughts in the $1981 / 1984,1988 / 1989,1991 / 92,2004 / 2005$ and recently during $2014 / 2015$ seasons had significant negative impacts on crops and livestock volumes and consequently on food security and livelihood in general (Mpandeli et al., 2015). Predicted impacts of climate change and the dominance of rain-fed agriculture in SA mean that climate change poses a sizeable challenge, characterised by poor and unreliable rainfall, frequent droughts and periodic flooding, especially within the context of an increasing population (Bogdanski, 2012). These challenges necessitate the uptake of sustainable technological innovations (Karakaya et al., 2014). The uptake of these innovations depends upon an understanding of the intersection of climate change, technological innovation and sustainable development in order to foster transitions to sustainable bio-economies at the global scale (Ingrao et al., 2016).

Climate-smart agriculture (CSA) recently gained prominence as a response to climate change (Asfaw et al., 2016; Campbell et al., 2014). CSA strives to sustainably increase agricultural productivity, national food security and incomes by adapting to and building resilience to climate change and by reducing greenhouse gas (GHG) emissions relative to conventional practices (FAO, 2010, 2013). CSA includes proven technologies and practices such as water management, intercropping, conservation agriculture and agroforestry (Government of SA, 2011; FANRPAN, 2013; Rojas et al., 2014). CSA consists of technological, policy and institutional interventions (Taneja et al., 2014) and is context dependent (Zilberman et al., 2012). Accordingly, particular regions require specific CSA interventions (Asfaw and Lipper, 2016). SA does not have a policy on CSA, but awareness is high and is likely to increase when CSA policies are put in place at national, provincial, and local levels (Mnkeni and Mutengwa, 2013). This is reflected by the number of projects and initiatives in SA whose objectives and activities are consistent with CSA principles. Consequently, understanding what CSA technological innovations (CSATIs) have been introduced or promoted and their characteristics could highlight challenges and opportunities for effective adoption of these technologies and practices.

Understanding the challenges and opportunities for effective technology adoption is important, as smallholder farmers in Africa are particularly exposed to climate change and need CSA (GraingerJones, 2011). Frequently, the term 'smallholder' is used interchangeably with 'small-scale', 'resource poor' and sometimes 'peasant farmer'. These terms refer to farmers' limited resource endowment relative to other farmers. These farmers generally have an average farm size of $0.5-2$ ha and operate under various constraints related to capital and labour, availability of inputs, or lack of knowledge (Drechsel et al., 2006). In SA, these farmers occupy the less developed and less resourced agriculture within small-based plots of land on which they grow subsistence crops and one or two cash crops (DAFF, 2012; Thamaga-Chitja and Morojele, 2014). Whilst the smallholder farmers have an important role in improving household food security (Wiggins and Keats, 2013), they face new challenges driven by climate change, and environmental and agricultural policy reforms; for instance, the SA agricultural sector faces water scarcity, which will increase with climate change (Baleta and Pegram, 2014). Hence, the best use of rainwater and maintenance of land productivity is critical. CSATIs at farm level have the potential to address climate-related challenges. However, inadequate technology adoption remains a challenge due to several barriers (Biazin et al., 2012; Long et al., 2016). Barriers include lack of financial or human resources, institutional capacity, information, education and technologies among others (Asfaw and Lipper, 2016; Gandure et al., 2013; Jack, 2009). Therefore, actions and strategies that enhance adoption and diffusion of CSATIs may be required. Consequently, knowledge of CSATIs, their characteristics and how these impact adoption is necessary.

Previous research focused on the impact of climate change on SA agriculture (Gbetibouo and Hassan, 2005; Maponya and Mpandeli, 2012b; Walker and Schulze, 2008), its sensitivity to climate change (Blignaut et al., 2009) and to decreasing water resources (Schulze, 2011). Knowledge gaps exist in relation to how socio-economic and other factors impact CSATIs adoption and diffusion in SA. A critical research area that will strengthen CSA research and practice includes understanding how socio-economic conditions interact with technology characteristics. Exploring the characteristics of technologies is the first step to understanding their adoption puzzle, including if there are potential gaps in available technological innovations and to theorise potential challenges that different actors (e.g. farmers) may face.

The aim of this study is to:

- identify specific CSA technologies related to water use and management available in SA,

- to describe their characteristics,

- the context of their application, and

- their potential to address climate change.

To achieve these objectives, this paper addresses the following research questions: What CSATIs are available in SA to address climate change related challenges? What are their characteristics and what is the context within which they are used?

To answer the research questions, the paper takes qualitative and inductive approach. This means that whilst we use and acknowledge existing theory and knowledge, we are open to new interpretations and sensitive to the specific empirical context. We do not develop nor test hypotheses, but rather explore the problem and identify available technologies and potential key factors for adoption through an open data collection process.

We first review key literature covering the specific climate challenges SA agriculture faces, broader CSATIs available to deal with these challenges, and the different categories available to characterise CSATIs. This review informs the development of a framework for categorising technological innovations. Subsequently, primary data is collected through semi-structured interviews with several groups of stakeholders including governmental officials, researchers (including both from stateowned research institutions (e.g. WRC, ${ }^{1} \mathrm{ARC}^{2}$ ) and selected universities), the private sector, farmer organisations and NGOs. The interviews provide data on specific CSATIs used within the SA context to mitigate climate risks and the key factors impacting their adoption. The framework for categorising CSATIs is then applied to explore the key characteristics of the available CSATIs, and how these characteristics may impact adoption. A discussion of the results follows which considers the implications for research, policymakers and practitioners.

\section{Literature review}

\subsection{Climate change risks and innovations to manage them in $S A$}

Drought causes problems for all farmers, however, small-scale farmers and subsistence farmers are most vulnerable (Maponya and Mpandeli, 2012a). An understanding of the risks and farmers' vulnerabilities is important to know to see if the technologies

\footnotetext{
1 Water Research Commission, see: www.wrc.org.za/.

2 Agricultural Research Council, see: www.arc.agric.za/.
} 
available are suitable (FAO, 2013). The risks facing African farmers include changing temperatures and rainfall patterns, increased drought, and floods (Hellin et al., 2012; Joshua et al., 2014; Ziervogel et al., 2010). In SA, the agricultural sector consumes about $65 \%$ of total available water (Blignaut et al., 2009). This, together with the current socio-economic and environmental context, signifies SA's vulnerability to climate change impacts (Ziervogel et al., 2014). Consequently, water is conceivably the key medium through which early (and consequent) climate change impacts will be felt; hence the need to establish resilience to the projected impacts (Schulze, 2011).

Table 1 gives an overview of the observed evidence of climate change and climate variability. Five (global) themes for categorising climate change and variability were identified in the literature. These themes were paired with specific climate change related risks in SA as well as existing innovations identifiable in the literature to reduce them. These studies show the impacts of climate change and how they reduce access to water, observed in the last two decades in SA. For instance, scenario projections for SA indicate reductions in summer rainfall ranging from $5 \%$ to $10 \%$ in the eastern part of the country whilst marginal increases in early winter rainfall is projected for the western part (Biazin et al., 2012; Blignaut et al., 2009). Temperatures are expected to rise by between $2.3{ }^{\circ} \mathrm{C}$ and $9.6^{\circ} \mathrm{C}$, while precipitation will fall by $2 \%$ and $8 \%$ by 2100 (Benhin, 2008). Farmers have also perceived temperature increases and declines in rainfall (Bryan et al., 2009). Mpandeli et al. (2015) concluded that Sekhukhune District in Limpopo Province, SA, experienced droughts for several decades. To respond to these challenges farmers employ a number of agricultural and technical activities in line with CSA principles, such as the adoption of drought-tolerant seed varieties and crops that require less water such as maize and sorghum, direct seeding, rainwater harvesting and zero tillage system among others. Therefore, the links between climate change, drought and the specific CSATIs are key criteria in selecting and finding available technologies.

\subsection{Classification of technological innovations}

Previously, innovations in agriculture have been noted for their role in the industrialisation of food production and recently for their potential to respond to climate change (Lybbert and Sumner, 2010; Pardey et al., 2010). Rogers (1995) popularly defined innovation as an idea, practice or object that is perceived as new by an individual or another unit of adoption. Toborn (2011) remarked that innovation is a "deceptively simple term but in reality, it ranges from embodied external innovations (seed, fertilisers, pesticides, etc.) to systems changes building on agronomic and managerial innovations (conservation agriculture, rainwater harvesting, etc.)". According to Toborn (2011), within the process of agricultural development, technology packages consist of various categories and simultaneous interventions of a non-technical nature, and therefore trying to understand them in isolation is unrealistic.

Many factors influence technology adoption (see Feder and Umali, 1993; Sunding and Zilberman, 2001; Rogers, 2003). These factors can be divided into three categories, namely; characteristics of technology, the farming environment into which the technology is introduced, and the farmer making the adoption decision (Morris et al., 1999). Three major paradigms for explaining adoption

Table 1

Climate risk for farmers and innovations for risk mitigation in the South African agricultural sector (based on synthesis of literature).

\begin{tabular}{|c|c|c|c|}
\hline $\begin{array}{l}\text { Global themes for climate } \\
\text { change risks }\end{array}$ & $\begin{array}{l}\text { Climate change and variability related } \\
\text { risk for farmers in SA }\end{array}$ & Innovations to reduce or manage risks & Sources \\
\hline \multirow{10}{*}{$\begin{array}{l}\text { Changes in average rainfall } \\
\text { patterns, with some regions } \\
\text { experiencing higher rainfall } \\
\text { and others less }\end{array}$} & \multirow{8}{*}{$\begin{array}{l}\text { Water scarcity caused by rainfall } \\
\text { variability and excessive non- } \\
\text { productive losses } \\
\text { Decrease in rainfall from the current } \\
\text { level and seasonal shifts of rainfall }\end{array}$} & $\begin{array}{l}\text { Micro and Macro catchments rainwater } \\
\text { harvesting; } \\
\text { Insitu rainwater harvesting }\end{array}$ & Biazin et al., 2012 \\
\hline & & $\begin{array}{l}\text { Drought tolerant crops to cope with declining } \\
\text { rainfall; }\end{array}$ & $\begin{array}{l}\text { Mpandeli et al., } 2015 \\
\text { Joshua et al., } 2014\end{array}$ \\
\hline & & Expansion of irrigation; & Ziervogel et al., 2010 \\
\hline & & Water saving and harvesting technologies; & Blignaut et al., 2009 \\
\hline & & Changes in cropping patterns, planting dates & Bryan et al., 2009 \\
\hline & & and land under cultivation; & Schulze, 2011 \\
\hline & & Conservation farming; & Gbetibouo and Hassan, 2005 \\
\hline & & Livelihood diversification & \\
\hline & Aridity & Rainwater harvesting & Kahinda and Taigbenu, 2011 \\
\hline & Precipitation will fall by $2 \%$ and $8 \%$. & $\begin{array}{l}\text { Improved farming technologies; } \\
\text { Irrigation }\end{array}$ & Benhin, 2008 \\
\hline \multirow{3}{*}{$\begin{array}{l}\text { Increases in the average global } \\
\text { temperature and heat waves }\end{array}$} & \multirow[t]{2}{*}{ Increasing average temperature } & Planting heat tolerant crops; & Joshua et al., 2014 \\
\hline & & Livelihood diversification & $\begin{array}{l}\text { Ziervogel et al., } 2010 \\
\text { Gbetibouo and Hassan, } 2005\end{array}$ \\
\hline & $\begin{array}{l}\text { Temperatures will rise by between } 2.3 \\
\text { and } 9.6\end{array}$ & $\begin{array}{l}\text { Heat tolerant crop varieties and animal breeds; } \\
\text { Supplemental feeds; } \\
\text { Crop residue cover }\end{array}$ & Walker and Schulze, 2008 \\
\hline $\begin{array}{l}\text { More intense and longer } \\
\text { droughts, particularly in the } \\
\text { tropics and subtropics }\end{array}$ & $\begin{array}{l}\text { Increased incidence of droughts and dry } \\
\text { spells }\end{array}$ & $\begin{array}{l}\text { Plant crops that require less water such as } \\
\text { drought resistant and early maturing varieties; } \\
\text { Alter agronomic practices }\end{array}$ & $\begin{array}{l}\text { Mpandeli et al., } 2015 \\
\text { Mpandeli, } 2014 \\
\text { Joshua et al., } 2014\end{array}$ \\
\hline \multirow{4}{*}{$\begin{array}{l}\text { Increased frequency of heavy } \\
\text { rainfall and extreme weather } \\
\text { events over most land areas }\end{array}$} & \multirow{4}{*}{$\begin{array}{l}\text { Localised floods; } \\
\text { Periodic flooding; } \\
\text { Water runoff; } \\
\text { Soil evaporation; } \\
\text { Decreased/varying river flow }\end{array}$} & Basin technique; & Joshua et al., 2014 \\
\hline & & Mulch technique; & Botha et al., 2007 \\
\hline & & Livelihood diversification & Mpandeli et al., 2015 \\
\hline & & & \\
\hline \multirow{3}{*}{$\begin{array}{l}\text { Rises in the average global sea } \\
\text { level }\end{array}$} & \multirow[t]{3}{*}{ Sea level rise } & Biological options (planting mangroves, estuary & Joshua et al., 2014 \\
\hline & & and wetland rehabilitation); & Cartwright et al., 2008 \\
\hline & & $\begin{array}{l}\text { Physical options (sea walls, barrages and } \\
\text { barriers, raising infrastructure, water pumps). }\end{array}$ & \\
\hline
\end{tabular}


decisions exist, namely: innovation-diffusion, economic constraint, and adopter perception (Adesina and Zinnah, 1993). Although all three paradigms are relevant, adopter perception is the least developed in the literature (Long et al., 2016; Wandji et al., 2012), warranting further exploration particularly to ascertain this aspect regarding CSA in SA.

Studies of farmers' perceptions in the context of adoption decisions regarding climate change (Adesina and Zinnah, 1993) have focused on problems such as soil erosion and land degradation. However, awareness about the problem needs to be balanced with knowledge about technological innovations designed to solve them. It is increasingly recognised that adoption alone may not achieve optimal outcomes owing to mismatches between the technological design and the context within which they are used (Long et al., 2016). Accordingly, farmers' perceptions of specific technology attributes are likely to condition their adoption decision (Assefa \& Van Den Berg, 2009; Mushunje et al., 2011; Pannell et al., 2006). Therefore, knowledge on the characteristics of the technologies will help us to explore their direct adoption or drivers and barriers for adoption.

Technological innovations can be characterised and classified according to several parameters. Table 2 provides an overview of categories for the characteristics of technological innovations based on the reviewed literature (see Toborn, 2011; Wandji et al., 2012). The characterisation of technological innovations can be based on their state of development, novelty, complexity, or the number of technical functions (Kaine et al., 2008; Diederen et al., 2003). For instance, a technology could either be mature or non-mature. When innovations first appear, potential users are hesitant regarding their effectiveness and are therefore inclined to view their use as experimental (Fernandez-Cornejo et al., 1994).

Furthermore, criteria to classify technological innovations include considerations of their objectives (i.e. prevention, resource-saving) and the distinction between incremental versus radical innovations (Henderson and Clark, 1990). Technologies may also be categorised based on their ability to save resources such as land and labour. This is worth exploring, given the rapid population growth, land pressures (Adesina and Chianu, 2002) and diseases pressures (such as HIV, resulting in a shortage of labour) that are present in Africa. Hybrid seeds which increase yield and are drought tolerant may lessen expansion of land for yield maximisation and help to address water scarcity related to climate change. Technologies such as new seed varieties (within unchanged production systems) are considered incremental and others, like integrated pest management and agroforestry, involve radical change (Loevinsohn et al., 2012). Since agricultural technologies usually address multiple, and at times conflicting objectives, ${ }^{3}$ it is necessary to balance the environmental objective of a technology with potential users' objectives, as a misfit could lead to non-adoption.

Technological innovations generally imply some type of investment in cash, labour or learning and farmers are likely to invest when they expect economic benefits in return (Sin, 2012). New technologies have a drawback because they involve high costs for farmers, dis-incentivising adoption, notably when adequate finance is limited (IWMI, 2006). For instance, initial investments in CSATIs such as macro-catchment rainwater harvesting systems and irrigation technologies may be unaffordable to poor farmers because of the costs of materials (Biazin et al., 2012; Hellin et al., 2012).

Besides technological attributes, the context in which technologies are being used (location), the people using them and how they are introduced by technology providers necessitate

\footnotetext{
${ }^{3}$ See http://dfid-agriculture-consultation.nri.org/summaries/dfidwp4.pdf.
}

deliberation (UN, 2011). Locally generated technologies are more likely to be compatible with farmers' current practices, potentially enhancing adoption (Morris et al., 1999). Farmers with secure markets for their produce are more likely to invest in and innovate with new technologies (DFIDWP4, 2004; IWMI, 2006). Another categorisation of CSATIs is their ability to enable climate change adaptation or mitigation and their impact on farm productivity (IPCC, 2011).

\section{Research approach and methods}

\subsection{Research approach}

This research utilises an exploratory and qualitative research approach. This is due to the nature of the research problem and the research questions. As is usual with such an approach, we seek rich and detailed data to build a clear picture of the research contexts and to answer the research questions, and do not develop nor test hypotheses. This is an appropriate approach for several reasons. First, CSA is a new concept and is still being defined (Campbell et al., 2014; Mutamba and Mugoya, 2014), meaning a qualitative approach enables an exploration and identification of available technological innovations and the factors that would affect their adoption. Second, the context of SA agriculture and climate impacts is likely to be important, as CSATIs are context specific. A qualitative approach allows a detailed consideration of this context. Third, we were seeking to explain what would inhibit the adoption of CSATIs, meaning a qualitative approach captures a wider set of impacts (rather than measuring a smaller set of previously existing factors).

In line with this, and as is explained in section 3.2 , we primarily used data collected through semi-structured interviews, supported with literature where appropriate. The suitability of this approach is based on the research questions, which involved exploring the availability and characteristics of CSATIs in SA, through different expert viewpoints. Literature review and interview data were the main sources of evidence to discover the relevant themes related to the research questions.

\subsection{Interview data}

An interview protocol was developed using the literature review (see Tables 1 and 2) and from discussions with knowledgeable key informants working in CSA in general and water management in particular. Considering the exploratory nature of this study, openended questions were posed for all interviews. The 43 questions contained in the protocol covered topics (as highlighted in Table 2) needed to answer the research questions, and discussions held with key informants were conducted to confirm the validity and appropriateness of the protocol (see the appendix). These themes comprised questions under the following headings;

- Respondents (interviewee) background.

- Institutional/Organisational perspective (about role, activities, initiatives of the organisations, and locations where CSA related initiatives are taking place).

- Existing and/or future expected water-related climate-smart agricultural technologies (about characteristics of CSATIs, importance CSATIs to smallholder farmers).

- Key factors that could impact the adoption of CSATIs.

Data collection was conducted from February to September 2015. Primary data collection was conducted in two steps. First, discussions were held with knowledgeable key informants $(n=5)$ to gain a general depiction of current issues concerning CSA in SA We contacted two professors from the universities of Limpopo and 
Table 2

Criteria for classification and characterisation of CSA technological innovations.

\begin{tabular}{|c|c|c|}
\hline Criteria to classify Technological Innovations (TIs) & $\begin{array}{l}\text { Relationship to adoption/How the characterisation may impact } \\
\text { adoption }\end{array}$ & Sources \\
\hline $\begin{array}{l}\text { Environmental objectives of TIs (i.e. prevention, resource } \\
\text { savings) }\end{array}$ & $\begin{array}{l}\text { Misfit between environmental objectives and potential user (e.g. } \\
\text { farmers) objectives could lead to non-adoption. }\end{array}$ & $\begin{array}{l}\text { Frondel et al., } 2007 \\
\text { Sin, } 2012\end{array}$ \\
\hline Integrated or add-on & $\begin{array}{l}\text { Add-on technologies are cost-effective relative to integrated } \\
\text { technologies, which may require changing production practices. }\end{array}$ & $\begin{array}{l}\text { Henderson and Clark, } 1990 \\
\text { Anderson et al., } 2010\end{array}$ \\
\hline Incremental or radical & $\begin{array}{l}\text { Incremental approach to technology adoption is likely to be } \\
\text { preferred by farmers when uncertain about technology because it } \\
\text { usually requires minor changes }\end{array}$ & Kaine et al., 2008 \\
\hline \multirow[t]{2}{*}{ Adaptation versus mitigation } & \multirow{2}{*}{$\begin{array}{l}\text { Balancing priorities will influence adoption decisions of farmers. } \\
\text { Farmers in Africa are less likely to invest in emission reduction if } \\
\text { there are few immediate benefits related to food or water security. }\end{array}$} & Government of SA, 2011 \\
\hline & & $\begin{array}{l}\text { Rojas et al., } 2014 \\
\text { Neufeldt et al., } 2013\end{array}$ \\
\hline \multirow[t]{2}{*}{ State of development and novelty } & Status of development of technology influences adoption. & Kaine et al., 2008 \\
\hline & $\begin{array}{l}\text { Immaturity impacts relative competitiveness of technology. } \\
\text { Investments in new innovations higher risk than in mature } \\
\text { technologies. }\end{array}$ & Diederen et al., 2003 \\
\hline \multirow{2}{*}{ Endogenous versus exogenous innovations } & \multirow{2}{*}{$\begin{array}{l}\text { Technologies generated locally are likely to be compatible with } \\
\text { current farming practices and thus stand a better chance of being } \\
\text { adopted. }\end{array}$} & Sonnino et al., 2009 \\
\hline & & Morris et al., 1999 \\
\hline $\begin{array}{l}\text { Management-intensive (MI) versus capital-intensive (CI) } \\
\text { technologies }\end{array}$ & $\begin{array}{l}\text { Factors influencing adoption of capital purchases and management } \\
\text { improvements tend to differ. Education and industry involvement } \\
\text { tend to influence adoption of MI technologies in contrast to CI } \\
\text { technologies which may appeal to producers of all education levels. }\end{array}$ & Zepeda, 1990 \\
\hline \multirow[t]{4}{*}{ Continuous versus discontinuous innovations } & \multirow{4}{*}{$\begin{array}{l}\text { Facilitating diffusion of information, capacitating the farmers and } \\
\text { their advisors may increase adoption. Switching costs to new } \\
\text { technology depend on knowledge, skills and provisions required to } \\
\text { make it work. }\end{array}$} & Toborn, 2011 \\
\hline & & Sin, 2012 \\
\hline & & Diederen et al., 2003 \\
\hline & & Fischer et al., 2015 \\
\hline \multirow{4}{*}{$\begin{array}{l}\text { Innovations according to impact (new or improved quality } \\
\text { products, increased yield, cost reduction); } \\
\text { Areas of environmental impacts (e.g. water) }\end{array}$} & \multirow{4}{*}{$\begin{array}{l}\text { Cost reduction and environmental impact influence adoption } \\
\text { decisions of farmers. Farmers with improved understanding of the } \\
\text { environmental impacts of their technological choices are more } \\
\text { likely to adopt environmentally friendly practices. }\end{array}$} & Toborn, 2011 \\
\hline & & Belin et al., 2011 \\
\hline & & Baumgart-Getz et al., 2012 \\
\hline & & Sin, 2012 \\
\hline \multirow[t]{2}{*}{ Labour and land saving innovations } & \multirow{2}{*}{$\begin{array}{l}\text { Where labour and land are scarce, technologies requiring more of } \\
\text { these resources are likely not to be adopted. }\end{array}$} & Toborn, 2011 \\
\hline & & $\begin{array}{l}\text { Adesina and Chianu, } 2002 \\
\text { IWMI, } 2006\end{array}$ \\
\hline Individual and collective innovations & $\begin{array}{l}\text { The focus is on individual adopter and groups of people for } \\
\text { individual and collective innovations, respectively. }\end{array}$ & Toborn, 2011 \\
\hline \multirow{3}{*}{$\begin{array}{l}\text { Embodied, exogenous innovations (EEI) and packages of } \\
\text { disembodied agronomic and managerial innovations } \\
\text { (PDAMI). }\end{array}$} & \multirow{3}{*}{$\begin{array}{l}\text { Where technology is embodied in capital good such as seeds, } \\
\text { fertiliser and pesticides, adoption may be improved as the } \\
\text { manufacturer may provide finance or guarantee a loan for its } \\
\text { purchase than with PDAMI such as conservation agriculture, } \\
\text { rainwater harvesting. }\end{array}$} & Morris et al., 1999 \\
\hline & & Sunding and Zilberman, 2001 \\
\hline & & Toborn, 2011 \\
\hline Low-cost versus high-cost technologies & $\begin{array}{l}\text { In instances where technologies are deemed high-cost, adoption is } \\
\text { likely to be low if farmers are not able to secure finances. }\end{array}$ & IWMI, 2006 \\
\hline $\begin{array}{l}\text { Technologies for household food security versus those for } \\
\text { market production }\end{array}$ & $\begin{array}{l}\text { Market-oriented production farmers are likely to adopt high-cost } \\
\text { technologies relative to those aiming to achieve own food security. }\end{array}$ & IWMI, 2006 \\
\hline
\end{tabular}

North West, officials from Limpopo Department of Agriculture (LDA) and Agricultural Research Council, Institute of Soil, Climate and Water (ARC-ISCW) and FAO official based in SA. The discussions provided insights based on the respondents' views and experiences. We gathered useful information from university officials about CSA in SA, technologies and practices being promoted, government initiatives and efforts in promoting and implementing CSA. Next, officials from Limpopo Department of Agriculture, Agricultural Research Council, Institute of Soil, Climate and Water and FAO officials based in SA were contacted to triangulate information gathered from the professors and the literature. The discussions with key informants made clear that several relevant projects and interventions in which they are directly or indirectly involved were taking place.

Second, interviews were conducted with 27 CSA stakeholders in SA from various organisations using a standardised interview protocol (see Appendix B). Nonprobability purposive sampling (Palinkas et al., 2013) was chosen, with referrals from existing contacts used to identify potential study respondents. Interview respondents had to be an employee of one of the organisations identified (through literature searches relevant to CSATIs or co- nomination) as relevant for CSA activities and initiatives, have or are working (in research or practice) in CSA in general and water management for agriculture in particular. Potential study respondents were contacted via email, telephone and invited to participate in the interview.

Questions of validity in qualitative research are not clear cut. However, the number of interviews conducted were felt to be sufficient for the research aims, since we reached a point where no new information was being acquired, and as such achieved data saturation (Miles and Huberman, 1994). Data gathered from our respondents was indicatively able to shed light on the available CSATIs in SA, their context of use and the factors affecting their adoption based on the knowledge, awareness and involvement of interviewees in relation to CSA activities. Furthermore, our research sample included multiple perspectives (such as public sector, research institutes and universities) which allowed triangulation, increasing validity. Finally, as the research takes an exploratory and qualitative form the quality of the data is the most important factor. See Appendix A for an overview of the respondents interviewed. 


\subsection{Data analysis}

We followed several steps to analyse the data. Firstly, we transcribed the data and during this process, we made memo's and noted key initial observations of the contextual information about details such as the project aims, the setting, participants, and topic guides (protocol) that where relevant. This process is important because transcribing is an interpretative act rather than simply a technical procedure, and the close observation that it entails can lead authors to notice unanticipated phenomena. Secondly, data was organised and sorted by looking closely at what the respondents were doing concerning CSA and related projects, specific CSATIs being promoted and their opinions about them, the opportunities for enhancing and challenges hindering CSATIs adoption. We coded individual data items based on their relevance to the research questions. The coding and categorisation process were conducted using Atlas.ti. We used a word-based technique (Ryan and Weisner, 1996) to identify the relevant themes to answer our research questions. For a theme to be developed, at least three of the respondents had to note the factor. We repeated this process to maximise internal consistency within the categories and until most data items were positioned into the recognised categories. After sorting the different codes into potential themes, we revised the potential themes to see if they help to understand what the key factors for adoption of CSA in SA.

For instance, R11 was an official who manages about 28 agricultural water management projects, looking at the areas of climate change, agriculture and irrigation within the research institution which supports sustainable development through research funding, knowledge creation and generation. During the interview, they noted that water availability in certain areas of SA is a problem due to climatic variability and change. They further noted that the issue for farmers is to obtain good yield, irrespective of their farming system (i.e. dry or irrigated land). The respondent noted that there is a need to adopt strategies consistent with CSA principles due to climate pressure and mentioned that good examples in SA include Conservation Agriculture (CA), Rain Water Harvesting (RWH), Decision support tools and Drought-tolerant seeds. R11, R15 and R3 acknowledged the potential of various CSATIs, but they were concerned about availability at village level and the affordability of these technologies by smallholder farmers. Some respondents noted that providing proof of benefits seemed to be a motivating factor, yet the benefits were not yet sensitised to most farmers. The coding process, in this case, started with identifying available CSATIs, their characteristics and factors likely to influence their adoption expressed by respondents. Therefore, the above excerpts were initially highlighted and then categorised based on commonalities or generalisations among various respondents. For example, respondents noted issues such as high price, lack of funds and availability of implements and we assigned them to the category of 'Availability and affordability of technology'. Concerns that people must see the technology benefits, demonstrations and sensitisation of benefits were also noted; and these were assigned to 'Proof of technology benefits' category. The description and characteristics of the available CSATIs in SA and key factors most likely to influence their adoption are elaborated in the results section.

\section{Results of the interviews}

\subsection{Available CSA technologies in SA}

During the interviews, CSA stakeholders in SA noted a set of technologies and practices consistent with CSA, which were promoted to respond to climate-related challenges. Table 3 highlights the technologies and practices identified through analysis of the interview data. The technologies and practices are not ranked nor ordered in terms of their importance but are presented to briefly explain and highlight their availability and their associated CSA impact. For example, the results show that the adoption of seed varieties is expected to enable harvest even under adverse conditions, whilst helping farmers to deal with dry spells and mitigate against rain shortfall. No direct mitigation impact is expected.

\subsection{Key factors affecting adoption of CSA technologies and practices}

To explore the context within which the above technologies are used, respondents were asked what they considered to be key factors for adoption and what capacities smallholder farmers require to adopt the available technologies and practices. The factors reported by the respondents were developed into themes during the analysis (see section 3.3 for explanation of the analysis approach). The themes are presented below and illustrated with respondent quotes (in italics):

1. Awareness raising and provision of knowledge and skills: Respondents noted that farmers may not possess sufficient knowledge and skills required to make new technologies work. Additionally, farmers need to be made aware of where and how to access these technologies

Visibility on our side. We do have a license to sell hybrids. The farmers need to know where seeds can be found. (R2)

Farmers need to be empowered with skills and knowledge tailormade to their needs, and in the language they understand. (R5)

2. Availability and affordability of technology: Respondents highlighted that unavailability and unaffordability of some technologies will affect their adoption, particularly by smallholder farmers. This theme comprised elements relating to the price of the technology and in some instances the fact that farmers lack financial resources to secure farming inputs. In other cases, the issue is in terms of supply where promoted technologies were not yet on the market.

First is the price of technology. Second is the operational costs and maintenance. (R11)

Lack of funds, as seeds are not cheaper. (R15)

Implements are not always available, especially at village level for smallholder farmers. (R3)

The main thing is in terms of acquiring the seeds because so far, the seeds are not yet available in the market. (R27)

3. Farmers' attitudes, age, and preferences: Respondents raised concerns about the ageing farming population in SA. Older farmers are often reluctant to change their practices and this can be a hindering factor to technology adoption. Respondents further noted that besides improved yield, farmers may prefer other attributes such as seed colours and type; and these also need to be considered when technologies are promoted and introduced.

Other farmers still prefer traditional methods and are reluctant to change. (R15) 
Table 3

Description of the CSA technologies and practices based on interview data.

\begin{tabular}{|c|c|}
\hline CSA technologies and practices & Potential CSA impact \\
\hline $\begin{array}{l}\text { Seed varieties (drought tolerant and early maturing): Seeds developed to tolerate } \\
\text { drought and mature early. }\end{array}$ & $\begin{array}{l}\text { Productivity/Incomes: Enable harvest even under adverse conditions. } \\
\text { Adaptation: Help farmers deal with dry spells and mitigate against rain shortfall. } \\
\text { Mitigation: No impact. }\end{array}$ \\
\hline $\begin{array}{l}\text { Conservation Agriculture: A production system based on } 3 \text { principles namely; } \\
\text { minimum or no tillage practice (minimum soil disturbance), permanent organic } \\
\text { soil cover (consisting of a growing crop or dead mulch of crop residues) and } \\
\text { diversified crop rotations. }\end{array}$ & $\begin{array}{l}\text { Productivity/Incomes: Provide options for increased profits and improve food } \\
\text { security. } \\
\text { Adaptation: Avoid structural degradation. Crop rotation can fix nitrogen (which } \\
\text { inhibits high prices of nutrients like fertilisers) and improve crop diversity. } \\
\text { Mitigation: Less fuel from limited tractor use, and less GHGs. Safeguard carbon } \\
\text { sequestration via carbon storage in the soil. }\end{array}$ \\
\hline $\begin{array}{l}\text { Rain Water Harvesting (RWH): Describe the range of techniques of concentrating, } \\
\text { collecting, storing, and using rainwater runoff. Two types noted; In-field Rain } \\
\text { Water Harvesting (IRWH) and Mechanised Basins }\end{array}$ & $\begin{array}{l}\text { Productivity/Incomes: Increases rainwater productivity and yields. } \\
\text { Adaptation: Helps to avoid risk of crop failure linked to erratic, declining rainfall } \\
\text { and high run-off through efficient rainwater management. } \\
\text { Mitigation: IRWH encompass No-till system, therefore, mitigation potential }\end{array}$ \\
\hline $\begin{array}{l}\text { Strip intercropping (SI): Practice of growing two or more crops together in strips } \\
\text { wide enough to allow separate crop production using machines and close enough } \\
\text { to permit crops interaction. Usually done with maize and leguminous crops for } \\
\text { nitrogen fixation. }\end{array}$ & $\begin{array}{l}\text { Productivity/Incomes: Increase productivity by maximising available land. } \\
\text { Adaptation: Allow farmers to diversify, thereby improving food security and } \\
\text { reducing risk of crop failure. } \\
\text { Mitigation: No impact. }\end{array}$ \\
\hline $\begin{array}{l}\text { Biochar }(B) \text { : A charcoal used as soil amendment. It is produced from plant matter and } \\
\text { stored in the soil as a means of removing carbon dioxide from the atmosphere. }\end{array}$ & $\begin{array}{l}\text { Productivity/Incomes: Potential to increase incomes of farmers in the presence of } \\
\text { increasing temperature. } \\
\text { Adaptation: Helps farms adapt to high evaporation from high temperatures by } \\
\text { locking water in the soil. } \\
\text { Mitigation: Reduces GHGs and enables sequestration since carbon is not lost } \\
\text { through the atmosphere but locked in the Biochar. }\end{array}$ \\
\hline $\begin{array}{l}\text { Precision Irrigation Scheduling (PIS): Irrigates as and when water is required using } \\
\text { sensor to detect moistures deficit. }\end{array}$ & $\begin{array}{l}\text { Productivity/Incomes: Enables many production cycles per year, hence income } \\
\text { security. } \\
\text { Adaptation: This is a water efficiency technology which tackles water shortage. } \\
\text { Mitigation: GHGs reduction possibility for those using generators. }\end{array}$ \\
\hline $\begin{array}{l}\text { Agroforestry }(A G) \text { : Land use management in which harvestable trees or shrubs are } \\
\text { grown among or around crops to maintain soil fertility and conserve moisture. }\end{array}$ & $\begin{array}{l}\text { Productivity/Incomes: Improve soil fertility which can enable farmers to produce } \\
\text { more yield. } \\
\text { Adaptation: Mitigates against soil infertility, erosion and conserve moisture. } \\
\text { Mitigation: Provides potential for planting trees that can sequester carbon. }\end{array}$ \\
\hline $\begin{array}{l}\text { Site-specific nutrient management (SSNM): Focuses on application of nutrients (i.e. } \\
\text { Nitrogen) to where needed in farm during the time the crop needs it. Assessment } \\
\text { of crop nutrients needs precede application. }\end{array}$ & $\begin{array}{l}\text { Productivity/Incomes: Saves nutrients, so larger area can be treated with the } \\
\text { nutrients at farmers disposal. } \\
\text { Adaptation: Help farmers to spot place fertilisers, hence reduce evaporation and } \\
\text { nutrients run-off. } \\
\text { Mitigation: Fertiliser use reduction may result in reduced GHGs emissions. }\end{array}$ \\
\hline $\begin{array}{l}\text { Water Saving Irrigation Technology (WSIT): Underground irrigation. Feeds root } \\
\text { system of crop by releasing water only when needed. Reduces evaporation and } \\
\text { limit water run-off, implying less/no chemicals go on groundwater table. }\end{array}$ & $\begin{array}{l}\text { Productivity/Incomes: Saves and make more water available for production. } \\
\text { Adaptation: Help farmers to adapt to dry spells by reducing evaporation } \\
\text { relatively higher than Subsurface Drip Irrigation. } \\
\text { Mitigation: Little impact. }\end{array}$ \\
\hline $\begin{array}{l}\text { Drought Early Warning Detection (DEWD): A decision supporting tool (e.g. early } \\
\text { warning system) for seasonal forecasts. }\end{array}$ & $\begin{array}{l}\text { Productivity/Incomes: Reduce production losses linked to uninformed decisions. } \\
\text { Adaptation: Help farmers to make informed decisions as they get the nature of } \\
\text { cropping season before it starts. } \\
\text { Mitigation: No impact. }\end{array}$ \\
\hline Agro-ecology (AE): Type of farming system which does not rely on external inputs. & $\begin{array}{l}\text { Productivity/Incomes: Encourage people to produce their own food. } \\
\text { Adaptation: Help farmers to reduce food insecurity. } \\
\text { Mitigation: No fertiliser application, an opportunity to reduce GHGs emissions. }\end{array}$ \\
\hline
\end{tabular}

Ageing farmers are reluctant to adopt new technologies. (R6)

Proper introduction of technologies to farmers. Take care of farmers' preferences, for example, seed colours, type, and quality in addition to yield varieties. (R16)

You also have to deal with attitudes and mindsets, more especially of farmers. (R11)

Change is difficult. It is an issue of mindset. (R25)

4. Provision of support and complementary programmes: Provision of sufficient support, such as subsidy programmes, was mentioned as important for the adoption of CSA technologies. However, a concern was raised that sometimes the government launches inharmonious programmes. Respondents stressed that the misunderstanding resulting from this may lead to non-adoption of CSA technologies, and therefore, suggest that CSA stakeholders need to coordinate their efforts and programmes to avoid confusing targeted farmers and unsolicited outcomes.

Lack of adequate support from government. Government advocates market-related practices and they would prefer GMOs over agroecology. (R19)

[...] Different viewpoints from stakeholders. Actors, government, and researchers don't speak the same language; there is a difference of opinions. For instance other programmes such as mechanisation programs are still on, and push conventional implements parallel to the promotion of conservation agriculture (CA). (R3)

Currently, there is competition, we are just introducing CA, but farmers are still familiar with mechanisation (i.e. conventional farming). (R4)

5. Need for immediate benefits: Respondents noted that the time frame of realising some benefits is likely to affect adoption of 
CSA technologies because farmers are interested in immediate benefits.

[...] Farmers don't have patience ... they require immediate benefits. (R13)

[...] I have realised that our farmers are only satisfied when they have yields that sustain them for one season, just for only family consumption. (R21)

6. Proof of technology benefits: The proof of technological benefits was notable as a motivating factor to adopt CSA technologies. This is related to factor 3 , that farmers are usually reluctant, and therefore awareness raising activities should include a demonstration of direct benefits at farm level.

Proof of benefits, people must see the benefits. (R9)

Demonstration of benefits can serve a motivating factor. (R5)

Benefits of conservation agriculture are not sensitised to all farmers. It becomes difficult for a person to become baptised before they are born again. (R4)

Of course, we do awareness first and people will mostly check whether there are benefits. (R22)

7. Involvement of end users of the technologies: respondents noted that failure to involve the end users (farmers) during the development phase can lead to non-adoption of CSA technologies. Hence, they suggested bottom-up approaches to technology development.

I think if you come up with technology and you have it all designed without involving farmers ... it will be like you are imposing the technology to them. Do not impose technology on farmers. Use innovation platforms to engage farmers. (R20)

Consultation with end-users of technologies prior to its development and introduction, bottom-up approach is vital. Respect culture and norms of communities. (R12)

\subsection{Reported characteristics of the CSA technologies}

Following the identification of the CSATIs introduced and promoted in SA as well as key factors that impact their adoption, the next step was to explore innovation variables. The innovation variables identified from the literature (see Table 2) allowed an exploration of the characteristics of the specific CSATIs promoted in SA. Table 4 provides a summary of characteristics of CSA technologies promoted in SA.

Respondents reported that all CSATIs are semi-continuous, requiring additional knowledge and skills to be taught to farmers. All CSATIs were promoted for their potential to increase yield.

[...] If you want smallholder farmers to adopt technology, obviously you need to capacitate them and demonstrate to them that this technology could assist you to save water, etc. (R10)

[...] Conservation agriculture also saves land as you use your land sustainably. More yields mean some land can be left to rest. (R25)

[...] Of course, these seeds save the land ... If you plant something that is high yielding, with the same hectares of land, you produce more. (R24)

Six CSATIs were considered to require high initial investment costs. Respondents noted that although the costs of these technologies are initially higher, they reduce over time. Out of three technologies which appeared important according to respondents, two ( $\mathrm{CA}$ and $\mathrm{RWH}$ ) were reported to be management intensive. Therefore, given the factors mentioned in subsection 4.2 , this may imply that farmers lacking money to purchase equipment may not opt to adopt those technologies whilst ageing farmers may avoid management intensive technologies. All CSATIs except for Agroecology were reported to be land saving since they have the potential to increase yield with the same hectares of land relative to their alternatives. Usual levels of labour would be needed with most of the promoted CSATIs (7 out of 11), although additional labour may be required to implement some. Regarding maintenance and operations, although four technologies were reported to have some implications, fundamentally, these technologies can be easily maintained and operated as farmers usually receive training. Other maintenance risks were not reported to be specific to CSA technologies.

With CA, the land equivalent ratio is better in smallholder farming. Total crop production is higher. Labour savings in commercial farming reduce tremendously but with smallholder farmers it depends. (3)

The biggest problem with CA is actually management of weed. It is labour intensive but it reduces with time. I wouldn't say the same problem you are dealing with today with regard to $C A$ would still be the same in 5 years' time. Of course, most of the things we are dealing with would be sorted over time. For example, weed will be suppressed over time. CA saves land because now you find the potential of your land as you build your soil structure, potential increases as well and you can produce more. (13)

Another characteristic of the CSATIs was the return on investment. Respondents reported that some technologies are associated with immediate benefits and some longer-term with benefits accruing in the future.

What we have seen is that significant impacts of CA are observable within on average 4-5 years. However, some changes can be seen in the first years. Nonetheless, hardly on the 1st year. (13)

$R W H$, if it is adopted by smallholder farmers, the return on investment is between 2-5 years. But that will depend on the geographical location where you are. (R11)

Benefits are immediate. You plant your seeds and then harvest the yield. (R16)

In summary, we identify available CSATIs in SA, their characteristics and key factors that may influence their adoption. Although respondents mentioned that all CSATIs were important, we looked closely at our data set and explored technologies based on their characteristics. Based on the characteristics noted by the respondents Conservation Agriculture (CA), Rainwater Harvesting (RWH) and Seed Varieties that are Drought Tolerant and Early Maturing seem to be the most suited technologies and practices for the promotion of CSA in SA, particularly among smallholder farmers. These technologies were promoted as early as 2000, suggesting they have an ability to enhance resilient livelihoods of farmers in the face of a changing climate. Table 4 provides a summary of the CSATIs promoted in $\mathrm{SA}$, which gives an indication of the important technologies for CSA in SA. 


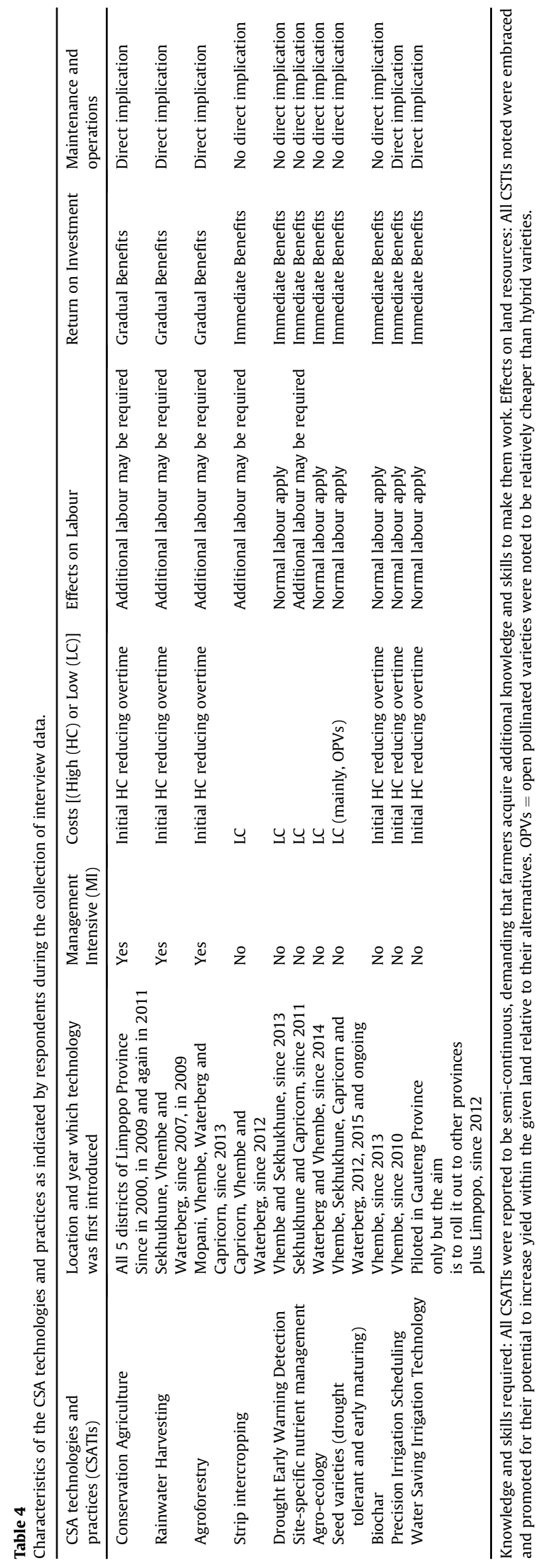

\section{Discussion of the results}

\subsection{Implication of the characteristics and interplay factors that affect adoption}

Respondents showed that SA smallholder farmers have been introduced to various CSATIs through a number of government programmes and private company interventions since 2000. However, these interventions do not always succeed in enhancing technology adoption by smallholder farmers due to several factors. Insights from respondents and literature were used as the basis for reflections regarding future challenges and opportunities for the adoption of CSATIs in smallholder farming and implications for future research.

Awareness raising, knowledge and skills provision were noted to be an important factor in influencing the adoption of CSATIs. These results concur with Diederen et al. (2003) who assert that knowledge and skills required to make a new technology work, determine switching costs and adoption rates. Respondents indicated that they created some level of awareness during the introduction and promotion of CSATIs to smallholder farmers, through the use of workshops, farmers' field days and experimental demonstrations. These methods, however, are insufficient for transferring all the necessary information about the technology to farmers (Jacobson and Myhr, 2013). Furthermore, Eidt et al. (2011), state that the effectiveness of sharing knowledge depends on how the knowledge is packaged. This could mean that alternative or additional knowledge transfer methods (tailored to smallholder context) are required and that information for farmers should be provided by multiple actors so that farmers are better able to judge the information given.

Availability and affordability are the second factors noted to impact on the possibility of CSATIs being beneficial to smallholder farmers. This is consistent with previous research (IWMI, 2006; Sin, 2012; Long et al., 2016), showing that high costs disincentivise farmers to adopt new technologies. Respondents indicated that many of the technologies have been supplied to smallholder farmers through government-sponsored interventions (freely or greatly subsidised), and according to Fischer et al. (2015), this suggests that farmers have not yet experienced the real costs of these technologies. This could further explain the perceived behaviour of farmers to abandon technologies at the end of projects (interventions) noted by some of the respondents.

Past research also points towards the influence of farmers' attitudes, age, and preferences on the adoption of technologies (Assefa and Van Den Berg, 2009; Mushunje et al., 2011). These concur with issues of ageing farmers and their attitudes towards new technologies which emerged as one of the key themes during the coding process. Another key factor identified as crucial to influencing adoption of CSATIs is if there is proof of a technology's benefits. This is related to the factor on awareness because the process of sensitising these technologies can be coupled with demonstrations of benefits, particularly in farmers' fields. Another justification for demonstrating benefits at farm level is related to the fact that smallholder farmers are operating in suboptimal agricultural environments which can produce different outcomes (Fischer et al., 2015).

Provision of support and complementary programmes was also noted to be strategic in influencing adoption of CSATIs in SA. This point tally's with Mnkeni and Mutengwa (2013) who noted that effective CSA implementation depends on clear policies and involvement of the necessary sectors. Hence, responsible organisations should monitor newly introduced technology and the adoption practices of farmers (Assefa and Van Den Berg, 2009; Eidt 
et al., 2011). Respondents further indicated that contradictory (e.g. tractor subsidy versus promotion of no-till planters) governmentfunded programmes jeopardise the chance of adoption of CSA technologies. This suggests that conflicting programmes can leave farmers confused and limit adoption (Mnkeni and Mutengwa, 2013).

Moreover, these results show that the benefits of the CSA technologies promoted in SA are not all immediate. This assertion is analogous with Fischer et al. (2015) who indicated that smallholder farmers are not able to absorb the losses associated with the waiting periods before the benefits, due to their lack of an economic buffer. Furthermore, lack of appreciation of users' needs and wants by technology developers and providers highlighted by Long et al. (2016) was indeed noted by the respondents as an influencing factor to technology adoption. Respondents suggested that a more bottom-up approach towards technology development as opposed to imposing of technologies could positively influence adoption by farmers.

\subsection{How innovation variables help us to understand the application of CSATIs in $S A$}

Exploring the criteria highlighted through the literature allowed successful consideration of how CSATIs apply in the SA context and further permitted us to deliberate on possible strategies to improve the effectiveness of CSA promotion efforts in SA. For instance, respondents noted that unaffordability and unavailability of technological innovations is likely to affect the adoption by farmers. This is expected as high-cost and capital intensive technologies were theorised (see Table 3) to have lower adoption rates. Additionally, respondents noted the importance of raising awareness and providing knowledge and skills as a factor to adoption. This relates to characteristics of innovations, such as continuous versus discontinuous, present within the wider technological innovation adoption literature.

The misfit between the environmental objectives and potential user objectives theorised to affect adoption in Table 2 was not mentioned explicitly by our respondents. However, the need for immediate benefits by farmers and involvement of end users of the technologies were noted, and this could imply that the objectives of farmers and goals of CSA need to be aligned to enhance adoption of CSATIs. Whilst the variables identified in Table 2 apply to agricultural contexts in SA and elsewhere, some respondents in our study noted that Agroforestry should be among prioritised CSATIs, yet literature shows that technologies like Agroforestry involve radical change (Loevinsohn et al., 2012). This could mean they are less likely to be adopted as compared to incremental technologies like new seed varieties. Therefore, future research could explore the conditions under which radical technological innovations would be most appropriate and what forms of support may be needed.

\subsection{Implication of the result for CSA efforts in $S A$}

The results of the study highlighted that several CSATIs introduced and promoted in SA require high initial investments. The availability and affordability of technology, noted to influence technology adoption, suggests that efforts to promote CSA technology adoption in SA need to be carried out through local supply channels and at affordable prices. Seeing that all CSATIs promoted in SA were found to be semi-continuous innovations, it is necessary that information channels to smallholder farmers be increased and that flaws (see Jacobson and Myhr, 2013; Mushunje et al., 2011) in how such information is transferred to them be avoided. For instance, CSATI providers and extension officers could join forces through a holistic educational campaign to enhance levels of information on CSATIs. This approach could help in tailoring information transfer and ensuring that farmers receive and understand the required information.

Some CSATIs promoted in SA are noted to be management intensive and requiring additional labour. Considering that most smallholder farmers are likely to be old farmers with physical weaknesses and lack labour for manual weeding (Assefa and Van Den Berg, 2009), it is fitting to target youth to enhance adoption of CSATIs in SA. A promising solution to these concerns is to invest in programmes that would encourage youth participation in agriculture as the country seeks to respond to climate change related challenges. Likewise, with regard to farmers' attitudes and preferences, the use of correct information dissemination channels regarding CSATIs could help in shaping smallholder farmers' perceptions to make informed decisions concerning the adoption of these technologies. For example, the creation of innovation platforms that are farmer-centred will give farmers a chance to learn and exchange knowledge with other stakeholders.

A conceivable alternative could be to engage smallholder farmers earlier in the innovation process to prioritise and support CSATIs that are more aligned to agro-ecologies and farming practices. This kind of approach, called user-centred innovation or cocreation, could enhance adoption of CSATIs because it helps to overcome several adoption barriers (see Long et al., 2016).

This study also identified gaps in knowledge that require further exploration to deepen our understanding of the CSA adoption puzzle in SA. This study provided the context of CSATIs in SA, their characteristics as well as factors likely to influence their adoption. To gain further understanding, future research should seek to identify the barriers and drivers of CSA technology adoption from the perspectives of farmers and technology providers. This may show how farmers perceive (see Mushunje et al., 2011; Wandji et al., 2012; for insights on the importance of perception) the barriers to the adoption of CSA technologies contrary or similarly to what the respondents of this study have said. This knowledge could assist other stakeholders in improving their offerings to smallholder farmers in SA.

This study is the first and crucial step in understanding and answering the 'what', 'how' and 'why' questions related to the CSA adoption puzzle in SA. This study forms a good basis upon which to inform the nature and scope of further investigations. Whilst a wider set of respondents could have been interviewed, we reached data saturation, highlighting that no new information existed. Although it is possible we have omitted some CSATIs, the research's contribution is unaffected due to the broader application of the results towards the successful adoption of innovations for sustainability in agricultural contexts. Further research could reveal other CSA technologies that respondents in this study were not aware of, which farmers are practising and/or are promoted by other stakeholders in the country. Results showed the important of awareness and access to information by farmers and how information is transferred in advancing CSATIs adoption. Future research could explore the effectiveness of different information dissemination channels used through government-funded programmes and/or private company interventions to transfer information on CSA technologies to farmers. It is likely that combinations of technologies may be needed to achieve better results with CSA efforts, so future research could also investigate how this occurs in practice. 


\section{Concluding remarks}

The study identified available CSATIs in SA and examined their characteristics and context of use, using an exploratory qualitative research approach. Data were collected by interviewing CSA stakeholders working in SA. The aim in taking this approach was to look at the adoption topic using the wider perspective of those who work in the field of CSA and water management for agriculture. Several CSATIs introduced in SA were identified and characterised. Through the exploration of the available CSATIs, this study serves as an initial assessment towards understanding the context of CSATIs in SA. This is essential given that the agricultural sector in SA is faced with the dilemma of responding to climate change related challenges whilst increasing the productivity of farmers.

Key results indicate that CA, RWH and Seed Varieties that are Drought Tolerant and Early Maturing seem to be the most suited technologies and practices for the promotion of CSA agriculture in SA. However, high initial investment costs and additional labour requirements, as well as management intensiveness associated with $\mathrm{CA}$ and $\mathrm{RWH}$, may render these technologies disadvantageous in the SA context, especially for smallholder farmers. Drought Tolerant and Early Maturing Seed Varieties, on the other hand, were noted to be less costly (particularly, OPVs), not management intensive and therefore may present better prospects of adoption, even by smallholder farmers. Results further indicate that awareness raising and effective transfer of information about the CSA technologies, provision of support and complementary programmes, demonstration of benefits and greater involvement of farmers early in the innovation process is essential in enhancing CSATIs adoption. Moreover, the results suggest that a holistic educational campaign to enhance the level of information regarding CSA technologies whilst involving the farmers from the onset has the potential to enhance adoption of these technologies.

\section{Acknowledgements}

The authors are appreciative of the financial support offered by Nuffic and other support provided by the University of Limpopo that enabled the $\mathrm{PhD}$ research project upon which this paper is based.

\section{Appendix A. Outline of Respondents}

Table A.1

CSA stakeholder data source/respondents and their expertise/professions

\begin{tabular}{|c|c|c|c|}
\hline No & Field of study & Responsibilities within the institution or organisation & $\begin{array}{l}\text { Institution or } \\
\text { Organisation }\end{array}$ \\
\hline R1 & Soil Science and Agronomy & Research scientist and farmers advisor & RI \\
\hline R2 & Agricultural Economics & Manager of a company which produces and sell certified seeds & PC \\
\hline R3 & Sustainable Agriculture & Manager and Facilitator of CA program & FA \\
\hline R4 & Engineering & Manager in the Section of Natural Resource Management & GO \\
\hline R5 & $\begin{array}{l}\text { Natural Resource Management and } \\
\text { Extension }\end{array}$ & Coordinating CA, Agroforestry and Soil Fertility Management and Land Care & GO \\
\hline R6 & Accounting and Finance Management & $\begin{array}{l}\text { President of the association. Interact with farmers and serve as contact person and representative of } \\
\text { farmers when it comes to interaction with other agricultural stakeholders }\end{array}$ & FA \\
\hline R7 & Agro-ecology & Conduct and lead research related to Global Change. Climate Change is one aspect of Global Change & $\mathrm{U}$ \\
\hline R8 & Meteorology and Agro-Meteorology & $\begin{array}{l}\text { Conduct research on climate change and variability and facilitate transfer of some mitigation and } \\
\text { adaptation technologies to farmers }\end{array}$ & RI \\
\hline R9 & $\begin{array}{l}\text { Sustainable Agriculture (Crop \& } \\
\text { Livestock) }\end{array}$ & Manager for research section. Oversee and facilitates all research activities & GO \\
\hline R10 & Geography (GIS and Remote Sensing) & Coordinate and manage research related to climate change across all water linked ecosystems & RI \\
\hline R11 & $\begin{array}{l}\text { Climate Change, Agricultural and } \\
\text { Irrigation Management }\end{array}$ & Manage agricultural water management projects & RI \\
\hline R12 & Soil Science & Researcher ( $80 \%$ of time spent in the field) & RI \\
\hline R13 & Environmental Management & Responsible for implementation of CA through training & RI \\
\hline R14 & Agro-Meteorology & $\begin{array}{l}\text { Manages the unit of climate change and disaster management which coordinates climate change } \\
\text { activities, agriculture, forestry and fisheries }\end{array}$ & GO \\
\hline R15 & Horticulture & Agricultural advisor to farmers in the division which focuses on development, particularly of farmers & PC \\
\hline R16 & Plant Breeding & Managing scientific research within research section & GO \\
\hline R17 & Plant Breeding & $\begin{array}{l}\text { Plant breeder. Lecture plant breeding, supervise post graduate students and conduct research } \\
\text { related to plant breeding and food security }\end{array}$ & $\mathrm{U}$ \\
\hline R18 & Soil Chemistry and Biology & Conduct research on Biochar which is part of mitigation research & $\mathrm{U}$ \\
\hline R19 & & $\begin{array}{l}\text { A project officer responsible for pre and post-settlements as far as redistribution programme (one } \\
\text { pillar of Land Reform) is concerned. }\end{array}$ & NGO \\
\hline R20 & Soil Science & $\begin{array}{l}\text { Conduct research on Precision Agriculture and Socio-economic Development. Conduct and assess } \\
\text { farmer needs and challenges }\end{array}$ & GO \\
\hline R21 & Soil Science & Advise farmers on irrigation management and conduct research on No tillage for maize crop & GO \\
\hline R22 & Agricultural Disaster Management & $\begin{array}{l}\text { Coordinator in the unit called Disaster and vulnerability management. Check all the hazards that } \\
\text { affect agricultural production }\end{array}$ & GO \\
\hline R23 & Agronomy & $\begin{array}{l}\text { Work under Home Grown (Food brand) and is responsible for primary agriculture where they } \\
\text { provide access to inputs to farmers through off-take agreements }\end{array}$ & PC \\
\hline R24 & $\begin{array}{l}\text { Agronomy and Farm and Business } \\
\text { Management }\end{array}$ & $\begin{array}{l}\text { Relate and work with farmers. Teach them how to grow maize because it is the company's main } \\
\text { resource they need. }\end{array}$ & PC \\
\hline R25 & $\begin{array}{l}\text { Sustainable Agriculture and Ecological } \\
\text { Remediation and Sustainable Use }\end{array}$ & Director in the directorate of land use and soil management. Responsible for land care. & GO \\
\hline R26 & Agricultural Engineering & Researcher within the agricultural mechanization and irrigation section & RI \\
\hline R27 & Agriculture: Agronomy & $\begin{array}{l}\text { Lecturing, supervision of students projects. Conduct research on indigenous vegetables, different } \\
\text { varieties of maize cultivars (e.g. WEMA) }\end{array}$ & $\mathrm{U}$ \\
\hline
\end{tabular}

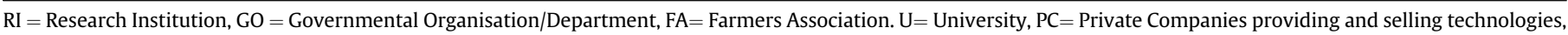
$\mathrm{NGO}=$ Non-Governmental Organisation. 
Appendix B. PhD Project Interview Protocol

\section{Climate-smart Agricultural Technologies (CSATs) related to water use and management in South Africa}

An in-depth interviewing methodology will be used to identify and characterise CSATs available in South Africa. The in-depth interviews (IDIs) will be conducted with various actors in agriculture to gather ideas of the technologies that identified actors thought to be appropriate and directed towards smallholder farmers. The interviews will explore the existing and expected CSATs related to water use and management in SA which are both directed at smallholder farmers and are available and/or expected to come in the market in the near future. The following topics/issues/questions will form the core of the interview guide for our IDIs:

Institutions:

Interviewee (Title and Name):

Interviewer:

A. Introduction

B. Survey Section to be Used:

I: Interview Background

II: Institutional Perspective

III: Existing and/or Future Expected water related Climate-smart

Agriculture Technologies (CSATs) Assessment

Other Topics Discussed:

Documents Obtained:

C. Post Interview Comments or Leads:

A. Introduction

We want to thank you for taking the time to meet with us today.

My name is

and we would like to talk to you about CSATs that exist in South Africa. Particularly, as one of the components of the PhD project on determining drivers and barriers to CSATs adoption we are identifying the water related CSATs that exist in SA and characterizing them based on a contextualized understanding of CSATS directed at smallholder farmers and their different attributes and context of application by farmers. We also want to gain insights about how different technologies are introduced and brought to farmers and your involvement with agricultural technology development and diffusion. You have been selected to speak with us today because you have been identified as someone who has a great deal to share about CSATs in South Africa since you have experience working here and to gain insights it is important for us hear your views and experiences.

We have planned this interview to take 45 minutes to an hour. During this time, we have several questions that we would like to cover. If time begins to run short, it may be necessary to interrupt you in order to push ahead and complete this line of questioning. Although we will be taking some notes during the session, we can't possibly write faster to get everything down. Because we don't want to miss any of your comments we would like to audio tape our conversations today. Please be sure to speak up so that we don't miss any of your comments. We will keep all responses 
confidential and only the research team members will be privy to the information and we will ensure that any information we include in our research report does not identify you as the respondent. Remember, your participation is voluntary and you don't have talk about anything you don't want to and you may end the interview at any time if you feel uncomfortable. We do not intend to inflict any harm.

Do you have any questions about what we have just explained? Are you willing to participate in this interview? (If yes, would you please sign below to meet our human subject requirements).

Interviewee

Date

B. Survey Section to be Used (Questions)

I. Interviewee Background

How long have you been ...

in your present position?

at this institution?

Interesting background information on interviewee:

What is your highest degree?

What is your field of study?

1. What does your institution do? (this can be filled from their website)......

2. Briefly describe your role (office, committee, position, etc.) as it relates to agriculture and farmers, technologies for water use and management (if appropriate).

\section{Institutional Perspective}

1. What is the strategy at this institution for improving development, diffusion and use of relevant technologies for climate change mitigation and adaptation?

Probes: Is it working - why or why not?

2. What resources are available to your institution for improving development, diffusion and use of relevant technologies for climate change mitigation and adaptation?

3. What kinds of networks do you see developing surrounding climate change mitigation and adaptation? (List them).

Probe: Has your institution subscribed to any of the network(s) mention above? (list them).

4. What are the potential constraints to improving development, diffusion and use of CSATs encountered in your department? . . Institution?.

Probes: How can these barriers be overcomed?

What are the major opportunities? How can they be maximized?.

5. In your view what is changing (issues on water quantity and quality) about availability of water resources for agriculture in this country (South Africa)?

Probe: What are your past, current and future initiatives related to use and management of water in agriculture (in the face of climate change) and how are they being accomplished? (e.g. Projects/programmes) 
III. Existing and/or Future Expected water related Climate-smart Agriculture Technologies (CSATs)

1. List of technologies that are considered CSA technologies and practices which are promoted in SA? (tick them as they are mentioned and write down additional ones)

a. Conservation agriculture (Minimum to zero tillage; cover crops; rotation)

b. Water management (Small-scale irrigation; Bunds/zai, tied ridge system; Water harvesting; Terraces, Contour farming)

c. Agroforestry (Live barriers, fences; crops on tree-land)

d. Soil Conservation structures

e. Soil and Water Conservation technologies

f. New traits, Varieties \& Crops

g. Others

Probe: Which of the above mentioned technologies are related to water use and management that could help crop farmers to mitigate and adapt climate change (CSATs)? (List them).

Probe: What CSA technologies related to water use and management that could help crop farmers to mitigate and adapt climate change have you developed and/or promoted? (List them)

Probe: Where in SA have you promoted the technologies and /or execute interventions (if you did) targeted at promoting the adoption of the identified technologies?.

2. Practical questions about the technologies (CSATs) you have developed and/or promoted and/or listed above:

a. What does the technology make? (factual/actual use for the technology)

b. What is its purpose? (what is designed for)

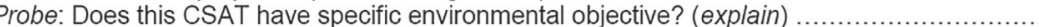

c. In your opinion is this technology add-on or integrated; incremental or radical? (circle what applies)

d. Where was the technology produced/manufactured? (imported/exported) (endogenous versus exogenous innovations). Probe: Do you think CSAT you mentioned above is compatible with existing practices and needs of smallholder farmers?.

e. In your view what do you consider to be the effects of the mentioned technology on the following; product quality, yield of farmers, cost of production and natural resources (i.e. environmental impact)

f. Does this technology deliver significant food security benefits to farmers and/or market potential?

g. Does this technology hold mitigation and/or adaptation potential?

Probe: For which farmers (small-scale or large-scale) and under which conditions (humid or dry areas)?

h. In your view is this technology management intensive or capital intensive; continuous or discontinuous innovation? (circle what applies and explain)....

i. Does this technology result in saving of labour and/or land?

j. For this technology, is the focus on individual adopter or group of farmers (land users)? (explain)

k. Is this technology considered low-cost or high-cost technology?

I. Is this technology an embodied, exogenous innovations (EEI) or packages of disembodied agronomic and managerial innovations (PDAMI)?

$m$. What is the state of development of this technology? (matured or non-matured)

$\mathrm{n}$. Is the technology applicable to (site specific) specific/every region?.

o. Can it be repaired and maintained by an ordinary person?.

3. What CSATs should be adopted by smallholder farmers? Why?. 
4. How are they/were introduced to farmers and/or implemented? When?

5. Do you recognize any barriers/impediments to the development, diffusion and use of relevant CSATs? (mention at least 4 which you think are critical).

Probes: At what level do you think/see barriers/impediments to the development, diffusion and use of relevant CSATs surfacing? (from inception and innovation stages to the transfer of technologies and the access to agricultural innovations (CSATs) by smallholder farmers).

What do you think can be done to address these barriers/impediments? (mention at least 5 suggestions/recommendations)......

6. Describe capacities of smallholder farmers that are required to enhance CSATs adoption and successful use. (mention at least 4 which you think are critical).

7. What types of development opportunities do you see emerging on your institution that focuses on technologies/techniques for climate mitigation and adaptation?.

C. Post Interview Comments or Leads

1. Is there anything more you would like to add regarding your institution and/or CSATs? (relevant observation)

2. I'll be analysing the information you and others gave me and during the writing process I may need to contact you again for clarification and further questions which might emerge from the analysis.

3. Thank you for your time and sharing your insights

\section{References}

Adesina, A.A., Chianu, J., 2002. Determinants of farmers' adoption and adaptation of alley farming technology in Nigeria. Agrof. Syst. 55, 99-112.

Adesina, A., Zinnah, M.M., 1993. Technology characteristics, farmers' perceptions and adoption decisions: a Tobit model application in Sierra Leone. Agric. Econ. 9, 297-311. http://dx.doi.org/10.1016/0169-5150.

Anderson, S., Gundel, S., Vanni, M., 2010. The Impacts of Climate Change on Food Security in Africa: a Synthesis of Policy Issues for Europe. International Institute for Environment and Development, London, UK.

Arslan, A., McCarthy, N., Leslie Lipper, L., Asfaw, S., Cattaneo, A., Kokwe, M., 2015 Climate smart Agriculture? Assessing the adaptation implications in Zambia. J. Agric. Econ. 66 (3), 753-780. http://dx.doi.org/10.1111/1477-9552.12107.

Asfaw, S., Lipper, L., 2016. Managing Climate Risk Using Climate-smart Agriculture. FAO, Rome Italy.

Asfaw, S., McCarthy, N., Lipper, L., Arslan, A., Cattaneo, A., 2016. What determines farmers' adaptive capacity? Empirical evidence from Malawi. Food Secur. Sci. Sociol. Econ. Food. Prod. Acce. Food. 8 (2) http://dx.doi.org/10.1007/s12571-0160571-0.

Assefa, Y. Van Den Berg J., 2009. Genetically modified maize: adoption practices of small-scale farmers in South Africa and implications for resource poor farmers on the continent. Aspec. Appl. Bio 96, 215-223.

Baumgart-Getz, A., Prokopy, L.S., Floress, K., 2012. Why farmers adopt best management practice in the United States: a meta-analysis of the adoption literature. J. Environ. Manag. 96, 17-25.

Baleta, H., Pegram, G., 2014. Water as an Input in the Food Value Chain. Understanding the Food Energy Water Nexus. WWF-SA, South Africa.

Belin, J., Horbach, J., Oltra, V., 2011. Determinants and specificities of ecoinnovations - an econometric analysis for the French and German industry based on the community innovation survey. In: Cahiers duGREThA, $\mathrm{n}^{\circ}$ 2011-17. http://ideas.repec.org/p/grt/wpegrt/2011-17.html.

Benhin, J.K.A., 2008. South African crop farming and climate change: an economic assessment of impacts. Glob. Environ. Chan 18, 666-678.

Blignaut, J., Ueckermann, L., Aronson, J., 2009. Agriculture production's sensitivity to changes in climate in South Africa. SA. J. Sci. 105, 61-68.

Biazin, B., Sterk, G., Temesgen, M., Abdu Abdulkedir, A., Stroosnijder, L., 2012 Rainwater harvesting and management in rainfed agricultural systems in subSaharan Africa - a review. Phys. Chem. Ear: 47-48, 139-151.

Bogdanski, A., 2012. Integrated food-energy systems for climate-smart agriculture. Agric. Food Sec. 1, 9. http://dx.doi.org/10.1186/2048-7010-1-9.

Botha, J. Anderson, J. Groenewald, D.C. Mdibe, N. Baiphethi, M.N. Nhlabatsi, N.N., Zere, T.B., 2007. On-farm Application of In-field Rainwater Harvesting Techniques on Small Plots in the Central Region of South Africa. WRC Report No. TT 313/07.

Bryan, E., Deressa, T.T., Gbetibouo, G.A., Ringler, C., 2009. Adaptation to climate change in Ethiopia and South Africa: options and constraints. Environ. Sci. Pol. 12, 413-426.

Campbell, B.M., Philip Thornton, P., Zougmoré, R., van Asten, P., Lipper, L., 2014 Sustainable Intensification: what is its role in climate smart agriculture? Curre.
Opin. Environ. Sust. 8, 39-43. http://dx.doi.org/10.1016/j.cosust.2014.07.002. Available at:

Cartwright, A., Brundrit, G., Fairhurst, L., 2008. Global Climate Change and Adaptation- Sea-level Rise Adaptation and Risk Mitigation Measures for the City of Cape Town Environmental Resource Management Department. Phase 4: Final Report.

Department of Agriculture, Forestry and Fisheries (DAFF), 2012. A Framework for the Development of Smallholder Farmers through Cooperatives Development. Available at: http://www.nda.agric.za/doaDev/sideMenu/ cooperativeandenterprisedevelopment/docs/FRAMEWORK-\%200F\%20SMALL $\% 20 F A R M E R S \% 20(2)$.pdf (Accessed on April 2016).

DFIDWP4, 2004. Technology and its Contribution to Pro-poor Agricultural Development. Available at: http://dfid-agriculture-consultation.nri.org/summaries/ dfidwp4.pdf (Accessed on February 2015)

Diederen, P., van Meijl, H., Wolters, A., Bijak, K., 2003. Innovation adoption in agriculture: innovators, early adopters and laggards. Cahiers d'Économie Sociol. Rurales 67, 30-50.

Drechsel, P., Olaleye, A., Adeoti, A, Thiombiano, L, Barry, B., Vohland, K, 2006. Adoption River and Constraints of Resource Conservation Technologies in Subsaharan Africa. Unpublished paper 21p Available at: https://cgspace.cgiar.org/ handle/10568/36743 (Accessed on 10 October 2015).

Eidt, C.M. Hickey, G.M., Curtis, M.A., 2011. Knowledge integration and the adoption of new agricultural technologies: Kenyan perspectives. Food Sec. 4, 355-367.

FANRPAN, 2013. Appropriate climate smart technologies for smallholder farmers in sub-Saharan Africa, 2 (XIII), 1-4

FAO, 2010. "Climate-Smart" Agriculture. Policies, Practises and Financing for Food Security, Adaptation and Mitigation". Available at: http://www.fao.org/docrep/ 013/i1881e/i1881e00.pdf (Accessed on September 2014).

FAO, 2013. Climate-smart Agriculture Sourcebook.

Feder, G., Umali, D.L., 1993. The adoption of agricultural innovations: a review. Tech. Forec. Soc. Chan 43, 215-239. http://dx.doi.org/10.1016/0040-1625.

Fernandez-Cornejo, J., Beach, E.D., Huang, W.-Y., 1994. The adoption of IPM techniques by vegetable growers in Florida, Michigan and Texas. J. Agric. Appl. Econ. 26 (1), 158-172.

Fischer, K., Van den Berg, J., Mutengwa, C., 2015. Is Bt maize effective in improving South African smallholder agriculture? SA. J. Sci. 111 (1/2), 2, \#a0092. http:// dx.doi.org/10.17159/sajs.2015/a0092.

Frondel, M., Horbach, J., Rennings, K., 2007. End-of-Pipe or cleaner Production? An empirical comparison of environmental innovation decisions across OECD countries. Busin. Strat. Environ. 16 (8), 571-584.

Gandure, S., Walker, S., Botha, J.J., 2013. Farmers' perceptions of adaptation to climate change and water stress in a South African rural community. Environ. Dev. 5, 39-53.

Gbetibouo, G.A., Hassan, R.M., 2005. Measuring the economic impact of climate change on major South African field crops: a Ricardian approach. Glob. Planet. Chan 47, 143-152.

Government of South Africa, 2011. South African Risk and Vulnerability Atlas. Department of Science and Technology, Pretoria, South Africa.

Grainger-Jones, 2011. Climate-smart smallholder agriculture: what's different?. In: 
IFAD Occasional Paper 3

Hardelin, J., Lankoski, J., 2015. Climate change, water and agriculture: challenges and adaptation strategies. Agric. Econ. Soci. Eur. Assoc. Agric. Econ. (EAAE). Euro Choices 14 (2), 10-15.

Hellin, J., Shiferaw, B., Cairns, J.E., Reynolds, M., Ortiz-Monasterio, I., Banziger, M., Sonder, K., La Rovere, R., 2012. Climate change and food security in the developing world: potential of maize and wheat research to expand options for adaptation and mitigation. J. Dev. Agric. Econ. 4 (12), 311-321.

Henderson, R.M., Clark, K.B., 1990. Architectural innovation: the reconfiguration of existing product technologies and the failure of established firms. Admin. Sci. Quart. 35 (1), 9-27.

Ingrao, C., et al., 2016. Agricultural and forest biomass for food, materials and energy: bio-economy as the cornerstone to cleaner production and more sustainable consumption patterns for accelerating the transition towards equitable, sustainable, post fossil-carbon societies. J. Clean. Prod. http:// dx.doi.org/10.1016/j.jclepro.2015.12.066.

IWMI (International Water Management Institute), 2006. Agricultural Water Management Technologies for Small Scale Farmers in Southern Africa: an Inventory and Assessment of Experiences, Good Practices and Costs. Final Report, Pretoria, South Africa.

IPCC (Intergovernmental Panel on Climate Change), 2011. Managing the Risks of Extreme Events and Disasters to Advance Climate Change Adaptation, a Special Report on Working Group I and Working Group II of the Intergovernmental Panel on Climate Change. Available at: http://www.ipcc.ch/ipccreports/ar4-syr. htm (Accessed on 08 March 2015).

IPCC (Intergovernmental Panel on Climate Change), 2007. Fourth assessment report: climate change (AR4). In: Chapter 8: Agriculture.

Jack, K., 2009. Barriers to agricultural technology adoption: market failures. In: White paper Prepared for the Agricultural Technology Adoption Initiative. JPAL (MIT)/CEGA, Berkeley, CA.

Jacobson, K., Myhr, A.I., 2013. GM crops and smallholders: biosafety and local practice. J. Environ. Dev. 22 (1), 104-124. http://dx.doi.org/10.1177/ 1070496512466856

Joshua, M., Abdulai Jalloh, A., Hachigonta, S., 2014. Review of Research and Policies for Climate Change Adaptation in Urban Areas in Southern Africa. Working Paper 101. Available at: www.future-agricultures.org. Accessed on 09-03-2015.

Juana, J.S., Kahaka, Z., Okurut, F.N., 2013. Farmers' perceptions and adaptations to climate change in sub-Sahara Africa: a synthesis of empirical studies and implications for public policy in African agriculture. J. Agric. Sci 5 (4), 121-135.

Kahinda, J.M., Taigbenu, A.E., 2011. Rainwater harvesting in South Africa: challenges and opportunities. Phys. Chem. Earth 36, 968-976.

Kaine, G., Hill, M., Rowbottom, B., 2008. Types of Agricultural Innovations and the Design of Extension Programs. Practice Change Research Working Paper 02/08. Victorian Government Department of Primary Industries.

Karakaya, E., Hidalgo, A., Nuur, C., 2014. Diffusion of eco-innovations: a review. Renew. Sust. Energy Rev. 33, 392-399.

Loevinsohn, M., Sumberg, J., Diagne, A., 2012. Under what Circumstances and Conditions Does Adoption of Technology Result in Increased Agricultural Productivity? Protocol. EPPI- Centre, Social Science Research Unit, Institute of Education, University of London, London.

Long, T.B., Blok, V., Coninx, I., 2016. Barriers to the adoption and diffusion of technological innovations for climate-smart agriculture in Europe: evidence from The Netherlands, France, Switzerland and Italy. J. Clean. Prod. 1-13. http:// dx.doi.org/10.1016/j.jclepro.2015.06.044.

Lybbert, T., Sumner, D., 2010. Agricultural Technologies for Climate Change Mitigation and Adaptation in Developing Countries: Policy Options for Innovation and Technology Diffusion, ICTSD-IPC Platform on Climate Change, Agriculture and Trade. In: Issue Brief No.6, International Centre for Trade and Sustainable Development. Switzerland and International Food \& Agricultural Trade Policy Council, Washington DC, USA, Geneva.

Maponya, P., Mpandeli, S., 2012a. Impact of drought on food scarcity in Limpopo Province, South Africa. Afric. J. Agric. Res. 7 (37), 5270-5277.

Maponya, P., Mpandeli, S., 2012b. Climate change and agricultural production in South Africa: impacts and adaptation options. J. Agric. Sci 4 (10), 48-60.

Miles, M.B., Huberman, A.M., 1994. An Expanded Sourcebook: Qualitative Data Analysis. Sage Publications, Thousand Oaks, USA.

Mnkeni, P., Mutengwa, C., 2013. State of climate smart agriculture in South Africa. In: A Scoping Study Report to the Food. Agriculture and Natural Resources Policy Analysis Network (FANRPAN).

Morris, M.L., Tripp, R., Dankyi, A.A., 1999. Adoption and Impacts of Improved Maize Production Technology: a Case Study of the Ghana Grains Development Project. CIMMYT, Mexico, D.F.

Mpandeli, N.S., 2014. Climate risks using seasonal climate forecast information in Vhembe District in Limpopo province, South Africa. J. Sust. Dev. 7 (5), 68-81.

Mpandeli, S., Nesamvuni, E., Maponya, P., 2015. Adapting to the impacts of drought by smallholder farmers in Sekhukhune District in Limpopo province, South Africa. J. Agric. Sci 7 (2), 115-124.

Mushunje, A., Muchaonyerwa, P., Mandikiana, B.W., Taruvinga, A., 2011. Smallholder farmers' perceptions on Bt maize and their relative influence towards its adoption: the case of Mqanduli communal area, South Africa. Afric. J. Agric. Res.
6 (27), 5918-5923. http://dx.doi.org/10.5897/AJAR11.918. Available at: http:// www.academicjournals.org/AJAR.

Mutamba, M., Mugoya, M., 2014. Climate-smart Agriculture: Farmers' Perspectives. Available at: http://ccafs.cgiar.org/publications/climate-smart-agriculturefarmers-perspectives (Accessed on October 2014).

Neufeldt, H., Jahn, M., Campbell, B.M., John R Beddington, J.R., DeClerck, F., De Pinto, A., Gulledge, J., Hellin, J., Herrero, M., Andy Jarvis, A., LeZaks, D. Meinke, H., Rosenstock, T., Scholes, M., Scholes, R., Vermeulen, S. Wollenberg, E., Zougmoré, R., 2013. Beyond climate-smart agriculture: toward safe operating spaces for global food systems. Agric. Food Secur 2 (12), 1-6.

New, M., 2002. Climate change and water resources in the south western Cape, South Africa. SA. J. Sci 98, 369-376.

Palinkas, L.A., Horwitz, S.M., Duan, N., Hoagwood, K., 2013. Purposeful sampling for qualitative data collection and analysis in mixed method implementation research. Admin. Polic. Ment. Health Ment. Health Serv. Res. 42 (5) http:// dx.doi.org/10.1007/s10488-013-0528-y.

Pannell, D.J., Marshall, G.R., Barr, N., Curtis, A., Vanclay, F., Wilkinson, R., 2006 Understanding and promoting adoption of conservation practices by rura landholders. Austr. J. Experim. Agric. 46, 1407-1424. http://dx.doi.org/10.1071 EA05037 (Accessed on 28 April 2015)

Pardey, P.G., Alston, J.M., Ruttan, V.W., 2010. The economics of innovation and technical change in agriculture. In: Handbook of the Economics of Innovation vol. 2, pp. 939-984. http://dx.doi.org/10.1016/S0169-7218(10)02006-X.

Rogers, E.M., 1995. Diffusion of Innovations, fourth ed. Free Press, New York.

Rogers, E.M., 2003. Diffusion of Innovations, fifth ed. The Free Press, New York.

Rojas, A., Rahlao, S., Alfaro, M., Engel, W., Dubeux, C., Gomez, C., Gutman, V., Jarvis, A., Kebreab, E., Rosales, R., 2014. An Assessment of Mitigation Potential of GHG in the Agriculture Sector: the Case of Argentina, Brazil, Chile, Colombia, Peru and South Africa. MAPS Programme.

Ryan, G.W., Weisner, T., 1996. Analyzing words in brief descriptions: fathers and mothers describe their children. Cult. Anthr. Meth. J. 8 (3), 13-16.

Schulze, R.E., 2011. Climate change and the South African water sector: setting the scene on a 2011 perspective. In: Schulze, R.E. (Ed.), A 2011 Perspective on Climate Change and the South African Water Sector. Water Research Commission, Pretoria, RSA, pp. 3-6. WRC Report TT 518/12, (Chapter 1).1.

Sin, I., 2012. The adoption of environmentally friendly technologies. Agric. Motu Note 12.

Sonnino, A., et al., 2009. Socio-economic Impacts of Non-transgenic Biotechnologies in Developing Countries: the Case of Plant Micro-propagation in Africa. FAO.

Sunding, D., Zilberman, D., 2001. The agricultural innovation process: research and technology adoption in a changing agricultural sector. In: Gardner, B. Rausser, G. (Eds.), Handbook of Agric. Econ., vol. 1. Elsevier Science B.V.

Taneja, G., Pal, B.D., Joshi, P.K., Aggarwal, P.K., Tyagi, N.K., 2014. Farmers' Preferences for Climate-smart Agriculture: an Assessment in the Indo-gangetic Plain. IFPRI Discussion Paper 01337.

Thamaga-Chitja, J.M., Morojele, P., 2014. The context of smallholder farming in South Africa: towards a livelihood asset building framework. J. Hum. Ecol. 45 (2), 147-155.

Toborn, J., 2011. Adoption of Agricultural Innovations, Converging Narratives, and the Role of Swedish Agricultural Research for Development? Discussion Paper version 2011-01-28.

UN-Water, 2010. Climate Change Adaptation: the Pivotal Role of Water. UN-water Policy Brief (Available at: http://www.unwater.org/downloads/unw_ccpol_ web.pdf) (Accessed on 20-02-2015).

United Nations (UN), 2011. Water for Food: innovative water management technologies for food security and poverty alleviation. In: United Nations Conference on Trade and Development (UNCTAD) Current Studies on Science Technology and Innovation, No 4.

Wiggins, S., Keats, S., 2013. Smallholder Agriculture's Contribution to Better Nutrition. Available at: http://www.odi.org.uk/sites/odi.org.uk/files/odi-assets/ publication-files/8376.pdf (Accessed on April 2016).

Walker, N.J., Schulze, R.E., 2008. Climate change impacts on agro-ecosystem sustainability across three climate regions in the maize belt of South Africa. Agric. Ecosys. Environ. 124 (1-2), 114-124.

Wandji, D.N., Pouomogne, V., Binam, J.N., Nouaga, R.Y. 2012. Farmer's perception and adoption of new aquaculture technologies in the western highlands of Cameroon. TROPICULTURA 30 (3), 180-184.

Zepeda, L., 1990. Adoption of Capital versus Management Intensive Technologies Agecon-wisc-0319. Available at: http://ageconsearch.umn.edu/86B1AF174A84-4665-875C-75312AAF691/FinalDownload/bitstream/200528/2/ageconwisc-0319.pdf (Accessed on 28 February 2015).

Ziervogel, G., Shale, M., Du, M., 2010. Climate change adaptation in a developing country context: the case of Urban water supply in Cape town. Clim. Dev. 2 94-110.

Ziervogel, G., New, M., van Garderen, E.A., Midgley, G., Taylor, A., Hamann, R., StuartHill, S., Myers, J., Warburton, M., 2014. Climate change impacts and adaptation in South Africa. WIREs Clim. Change 2014 (5), 605-620. http://dx.doi.org/ 10.1002/wcc.295.

Zilberman, D., Zhao, J., Heiman, A., 2012. Adoption vs. adaptation, with emphasis on climate change. Annu. Rev. Resou. Econ. 4. 